\title{
Students' Roles in Learning English through Mobile Assisted Language Learning (MALL): A Teachers' Beliefs View
}

\author{
Hafidz Wahyu Nur CHOLIS', Endang FAUZIATI², Slamet SUPRIYADI ${ }^{3}$
}

\begin{tabular}{l} 
ARTICLE INFO \\
\hline Article History: \\
Received 04.04 .2020 \\
Received in revised form \\
28.01 .2021 \\
Accepted \\
Available online 01.04 .2021
\end{tabular}

\begin{abstract}
This study aims to explore teacher's beliefs about students' roles in learning English through MALL and the factors contributing to their beliefs. MALL which stands for Mobile Assisted Language Learning were the main instructional media where there was no such direct physical meeting in school. This media became popular nowadays, despite its emergence in the early 2000s, especially during Covid-19 pandemic which prevents both students and teachers to have direct physical meeting in the classroom. It was important to understand what role should be played by the students which in this research was viewed from teachers' beliefs perspective. Therefore, the research questions formulated by the researcher were; (1) What are teacher's beliefs regarding students' roles in learning English through MALL? (2) What are the factors shaping their beliefs? In terms of methodology employed by the researcher, this research was qualitative with descriptive case study design. The subjects of this research were two teachers of Senior High School in Surakarta, Indonesia who were teaching English through MALL since 2017. The subjects were a Javanese male and Bataknese female who were 37 years old. Both of teachers had master degree from English Education Department. The instrument employed to acquire the data was interviews. The data then were categorized into the students' roles based on the theories. The result indicated that four students' roles became something that the teacher held as the truth. Those roles were participant, initiator, performer, and passive receptor. Meanwhile, the factors determining teacher's beliefs were discovered five factors.
\end{abstract}

(C) IJERE. All rights reserved

\section{Keywords: ${ }^{1}$}

MALL, Mobile Assisted Language Learning, Students' Roles, Teacher's Beliefs.

\section{INTRODUCTION}

The development of technology changes the way of people life including educational field. For example, digital tools help students with different abilities to access the curriculum by linking academic purposes to the real world (Ataman, 2020; Duman \& Karagöz,2016 ;Price-Dennis, Holmes, \& Smith, 2015, as cited in Picton, 2019). Besides, technology could improve grades of students, assist them learning, build their confidence, and keep their focus (Williams, 2020). Thus, technology provides positive impact on the development of educational field. One of those implemented technology in education is MALL which stands for Mobile Assisted Language Learning. According to Valarmathi (2011), MALL is a method to learning of language which is supported or enhanced through the handheld mobile device usage. In addition, mobile learning is new learning model that allows students to access learning materials and learning activities without limitations to place and time via the Internet and a wireless network (Lan \& Sie, 2010). This verifies the support of MALL to language teaching and learning process. Some characteristics of MALL are portable, social interactive, context sensitive, connectivity, and individualistic (Klopfer, Squire, and Jenkins (2002). Therefore, based on those characteristics, some devices, which are integrated to MALL, are mobile phone, tablet (e.g. iPad and Microsoft Surface), MP3/MP4 player (e.g. iPod), Personal Digital Assistant (PDA), and electronic pocket dictionaries (Burston, 2013). Those devices mentioned are not limitation to MALL devices. Along with technology development, there might be someday other devices which are incorporated in MALL. The integration of MALL in the classroom is to support language teaching and learning process. Geddes (2004) stated that along with mobile technology development, it could support second or foreign language teachers and learners to get greater opportunity in practicing target language "anywhere and anytime." Even, most of researcher agreed that the prospective effect of MALL on second language learning is substantial (Jee, 2011). Besides, Motallebzadeh and Ganjali (2011) revealed that student who received the vocabulary through mobile phone had better retention of vocabulary in contrast to whom did not have it through mobile phone. Therefore, as long as students bring their mobile devices that could access and control for learning, they are be able to study borderless which endorses ubiquitous learning (Lee, 2013). The ubiquitous learning through MALL is currently promoted by most, if it could not be said all, of educational field stakeholders. It is due to Covid19 pandemic which prevents teachers and students to meet physically in the school since the virus is very contagious and might risk their health even their life. This means that MALL is applicable and even reinforces language teaching and learning process.

Teacher's beliefs become sustained discussion since then. Pajares (1992) defines beliefs as values, perspectives, cognition, values, attitudes, and BAK (beliefs, assumptions, and knowledge). In addition, beliefs as BAK that define the teacher process to make a decision are proposed by Woods (1996). However, Borg (2003) emerges the term teacher cognition and no longer teacher's beliefs to define "the unobservable cognitive dimension of teaching - what teachers

\footnotetext{
Corresponding e-mail: ${ }^{1}$ hafidzwahyu10@gmail.com, orcid.org/0000-0002-3036-0141, Universitas Sebelas Maret

2 efauziati@gmail.com, orcid.org/0000-0001-8621-1412, Universitas Muhammadiyah Surakarta

3 pripus.lppmuns@yahoo.co.id , orcid.org/0000-0002-2148-5305,Universitas Sebelas Maret
} 
know, believe, and think" whereas Clark and Peterson (1986) stated that beliefs include know and think. In summary, teacher's beliefs are tacit and unconscious intention that people hold to be true (Fauziati, 2017).

Teacher's beliefs determine their decision-making and action in the classroom which make it necessary to discover the source of their beliefs. Borg (2003) proposes the obvious design of the correlation between the sources of teacher's beliefs, their own beliefs, and classroom practices. It is very helpful to track the source of teacher's beliefs which could affect teaching and learning process due to the teacher behavior and attitudes in the classroom. Larenas, Hernandez, and Navarrete (2013) stated that beliefs carry teacher's behavior and enlighten teacher's practices by aiding as informative framework which diminishes the obscurity of what they do in the classroom. Moreover, Stuart and Thurlow (2000) reported that teacher's beliefs and attitudes had been acknowledged as a substantial factor in teaching. This confirms the important role of teachers' beliefs in the classroom. Even Gilakjani and Sabouri (2017) testify that teacher's beliefs effect is bigger in contrast to the teacher's knowledge on their adopted decisions types, on their lesson plan, and on their practices in the classroom. Therefore, teachers' aims, their roles, procedure, and their students are prominently influenced by their beliefs (Kuzborska, 2011). In addition, Kindsvatter, Willen, and Ishler (1988) as cited in Richards and Lockhart (1996) proposed the source of teacher's beliefs which come from teachers' very experiences as language learners, successful practice of what runs best previously, mature practices, factors of personality, values based on research or education, and philosophies acquired from a method or approach.

Teaching and learning activities in the classroom consist of many components. One the component is students' roles which were defined by Larsen-Freeman and Anderson (2013) as the part that the student played in accomplishing learning task, social relationship, and interpersonal bond among students. Richards and Rodgers (2014) revealed the possible roles of the students occurred in the language classroom as passive receptor, performer, processor, problemsolver, initiator, and participant. These roles could simultaneously change during the lesson in order to adapt to the teaching method used by the teacher. Besides, the roles shifting could be also affected by the personality of the students. Therefore, it is thought provoking to explore students' roles when the teaching and learning process is not conducted physically, but virtually through MALL.

Since its emergence, MALL had been discussed by many experts with various elements that were explored and investigated. Here, some previous researches related to MALL are provided to delineate the position of this research as gap filler into them. In a study by Huang and Lin (2011), they investigated EFL students' preference between reading via mobile phone and hard copy. The result did reveal that students preferred hard copy for the lengthy assessments while they favored mobile phone as the best device of reading for shorter texts.

Another research by Miangah and Nezarat (2012) investigated the advantages and disadvantages derived from using mobile technologies for students as well as professionals. Particularly, the study seized the use of mobile phones in learning English as second language, which consist of vocabulary, listening, grammar, phonetics, and reading comprehension. The study was literature study that elaborated the researches of MALL that had been conducted by previous researchers. The results concluded that even though many researches had been carried out towards MALL technology in language learning, there were still so many works left to be done and a large amount of information to be uncovered. Moreover, the methods with the help of which mobile device technology could be used to provide a more robust learning environment had to be further improved.

In addition, Ertmer, Ottenbreit-Leftwich, Sadik, Sendurur, and Sendurur (2012) examined the teacher beliefs and the integration of technology in twelve K-12 classroom teachers. The study aimed to investigate the alignment of pedagogical beliefs and classroom technology practices of teachers recognized for their technology uses. The study was multiple case-study method. The results proposed near configuration that student-centered beliefs based on studentcentered practices (authenticity, student choice, collaboration). Moreover, teachers with student-centered beliefs be likely to endorse student-centered programs regardless administrative, technological, or assessment barriers. Teachers' beliefs and attitudes about the technology relevance to the learning of students were recognized to be the biggest impact on their success.

Furthermore, Khubyari and Narafashan (2016) examined the effect of MALL on reading comprehension of EFL learners. The study focused on intermediate female EFL students in Iran that were observed under experimental study of experimental and control groups. The results implied that EFL learners favored reading comprehension through mobile phones due to the convenience facilitated by the portability and accessibility of the mobile phone.

Moreover, Yudhiantara and Nasir (2017) conducted research to investigate the students' perception towards mobile phone to support classroom activities and student experience in using mobile phone to support classroom activities. This study was performed using qualitative method through questionnaire and observation. The results implied that students showed positive perception and attitude towards MALL to support classroom activities, whether through reading e-books, playing audio and video file, or operating online dictionary.

Based on the previous research, not many researches discuss students' roles especially from teacher's beliefs view. It triggers the researcher to conduct a research to explore teacher's beliefs about students' roles in learning English through MALL. Hence, the research questions formulated are

1. What are teacher's beliefs regarding students' roles in learning English through MALL?

2. What are the factors shaping their beliefs? 


\section{METHOD}

This research was qualitative research which used descriptive case study method. Yin (2018) stated that descriptive case study method provides meticulous and comprehensive description through sample evaluation in depth and detail. Thus, the main goal of this research is to explain the data gathered from interviews which describe teacher's beliefs regarding students' roles in learning English through MALL and the factors shaping their beliefs.

Then, the participants of this research were two teachers of Senior High School in Surakarta, Indonesia. The participants were male and female teachers with master degree educational background. The male participant was Javanese while female participant was Bataknese and both participant was 37 years old. Those participants were selected purposively due to their experiences in employing MALL as the main media of language teaching and learning activities since 2017. It was far before the Covid19 pandemic that forces most even all teachers and lecturers nowadays to have class online through MALL.

In addition, the data collection technique employed by the researcher was interviews. The interviews were in openended questions to obtain comprehensive data regarding the researched problem. The interviews were used to attain the data in form of information about teacher's beliefs regarding students' roles in learning English through MALL and the factors shaping their beliefs. Besides, the researcher stored the interviews data by using a voice recorder.

Furthermore, the acquired data were analyzed by using interactive model of analysis proposed by Miles, Huberman, and Saldana (2014). The first step, it was discarding unrelated data in order to make them sharp, focus, and organized which accordingly could be verified and drawn a conclusion. Secondly, the researcher displayed the condensed data in order to be interpreted. Finally, the researcher drew conclusion and verified the result.

\section{FINDINGS}

This section provides the findings from the attained data which are followed by the discussion related to the analyzed data. It consists of two parts which are based on the formulated research questions. The first part discusses about teacher's beliefs regarding students' roles in learning English through MALL. Afterwards, it discusses about the factors shaping their beliefs.

Teacher's Beliefs about Students' roles in Learning English through MALL

Through the interviews, the researcher found teacher's beliefs about students' roles in learning English through MALL. The data confirmed that from two participants, there were found fours students roles which were believed by the teachers. Those roles were passive receptor, participant, initiator, and performer. In terms of the students' roles as passive receptor, the second teacher (T2) stated,

"In my point of view, students just need to pay attention to explanation from the teacher, answer the question from the teacher, and complete the task given by the teacher" $(T 2,2020)$.

The statement above portrays the T2 beliefs about students' roles as passive receptor in learning English through MALL. First, they ought to receipt numerous data from the teachers inactively without any protest. Second, they were required to reply teacher's question effectively as in case they get the lesson. However, the informants did not give clear explanation why the students ought to be a passive receptor. The informants' perception within the course upheld their beliefs. The findings appeared that the nature of students would continuously pay attention to the teacher's explanation. They had commitment to do it due to their needs as students to get the information and the culture to regard the instructor as somebody who they look up.

Meanwhile, the first teacher (T1) affirmed that students must engage actively in the process of learning through MALL. It could be seen from the testimony below.

"For me, students should participate and actively engage in the teaching and learning process....

...set by themselves the goals they want to achieve and discuss it with the teacher...

...find the best learning strategies that suit them so that they could understand the material well....

...be able to monitor their progress in learning with the help from the teacher" (T1, 2020).

The testimony above illustrates the T1 beliefs about students' roles as participant in learning English through MALL. The statement from the informant above outlines his belief in reading teaching through MALL that students should be participants. Based on these data, the students should actively participate in distance learning, such as asking several questions related to unclear materials or instruction from the teachers. Students were obligated to develop themselves, such as showing off their abilities, to find the best learning and reading strategies for them, and to find ways to solve the problems they face.

In addition, the informant also assumed that the students who played the role of participants could monitor their learning progress, such as learning weaknesses in certain aspects of reading. However, they needed to seek help from teachers to solve their problems to show that they were willing to improve their skills. Therefore, there would be a cooperation between the teachers and the students to achieve successful learning.

The next discovered students' role was initiator. This role was confirmed by T1 which should be played by the students in learning English through MALL. It could be seen from the report below.

"Also, I think that the students could negotiate with the teacher about the material or task which is more difficult than others....

...could be able to negotiate the technique used by the teacher to teach the material.... 
...check their understanding before doing the task so that they can complete the task correctly....

...always communicate with the teacher regarding everything related to the teaching and learning process....

...be brave to convey their idea to both the teacher and their friends to make the classroom alive" (T1, 2020).

The report above indicates the students' role as initiator believed by T1. The above findings indicate that the informant believed that the student as the initiator should be able to ask the teacher to provide more explanations for difficult materials or guidance. Since it was considered impolite, it was certainly not done by ordering the teacher, but by negotiation. In addition, they could persuade teachers to use certain skills that are beneficial to students, so that students could learn enthusiastically and actively.

In addition, the results show that the informant assumed that the student as the initiator should always ensure that the teacher's instructions were clear. They needed to confirm their understanding of the instruction, because they must complete the task according to the teacher's guidance. Therefore, there should be a match between teachers' expectations of teaching and students' understanding of teaching itself. In addition, the informant also admitted that students who played the role of initiator should always communicate with teachers on all matters related to the teaching process in order to provide teachers with information about their learning status.

Besides, the above statement of the information provider explained his belief in reading teaching through MALL that students should act as initiator. Students should have communication skills in class and skill to interact with the teacher in formal spoken or written language. This means that in the absence of confirmation and negotiation, the teachers did not have to use all their own strength to do any homework. The teachers must also be able to be a good listener so that they could create interactive lessons based on the abilities of students without burdening them. When students were allowed to talk about their views on the topic, they felt considered and participated in the learning process. They would feel satisfied when they could express their difficulties in understanding the material and enabled them to identify their weaknesses in the course. This was very beneficial to teachers. They would strengthen the teaching of difficult materials.

Subsequently, both T1 and T2 argued the same about students' roles which they act as performer. Their avowal is displayed below.

"Students should also respond actively to the explanation delivered by the teachers and then express their understanding without any hesitation....

...students must express what they feel about the lesson including their depression due to difficult material or task" (T1, 2020).

"They should be more active in responding the instruction given by the teacher....

... actively ask the teacher whenever they don't understand the material, instruction, or task....

...not afraid to state what they think and feel about the lesson....

...even they can share their personal problems that might hamper learning process....

... free to give a comment or feedback to their classmates" $(T 2,2020)$.

The avowal above depicts students' roles in which they play as performer that held by the teachers as their beliefs. The data show that the informant assumed that the students as performers should actively respond to teacher guidance. It was when the students were keen to follow the guidance from their teachers. They did not only answer the questions given, but they could also compare or explain between two or more possible questions.

In addition, the informant believed that the students as performers could express their understanding of the material without a doubt. The students should not be shy to tell the teacher their level of understanding of the materials provided by the teacher so that the teacher knew the progress made by the students. The students could voluntarily tell the teacher, or the teacher asked the students to tell them their understanding of the material.

Moreover, the above results indicate that the informant believed that the students as performers should be able to tell the teachers how they felt about the teaching process. Their feelings included frustration due to difficulty in completing tasks or understanding the materials provided by the teacher. Once they found that they had difficulties in understanding materials, instruction, or tasks, the students were also expected to take the initiative to ask questions to the teacher. Therefore, the teacher could give further explanations and even evaluate its content, instruction, and tasks.

However, it should be aware that students' role as initiator and performer somehow overlaps each other. Concisely, the role of initiator is commonly impulsive desire from the students. In contrast, the role of performer is sometimes their impulsive desire to some extent and forcedly pushed by the teacher who intentionally created such instruction and activity that make the students respond and engage to the instruction given and activities managed.

\section{Factors Shaping Teachers' Beliefs}

According to the interviews, the researcher revealed the factors which lead teacher's beliefs about students' roles in learning English through MALL. The data verified that from two participants, there were found five factors which influenced teachers' beliefs. Those factors were teachers' very experiences as language learners, successful practice of what runs best previously, mature practices, values based on research or education, and philosophies acquired from a method or approach. When they were asked how they got such beliefs, the second teacher (T2) explicated, 
"...I had been a student also....this worked well gradually since I upgraded and updated the class instruction and activities based on teaching evaluation from the first using MALL.... adjust my teaching principle based on the method I use such as when using MALL right now" (T2, 2020).

The explanation above portrays the factors shaping T2 beliefs which came from teacher's very experience as language learner, successful practice of what runs best in the past, and values acquired from a method or approach. The informant said that her beliefs were directed by her experience as students so that she knew how the students were supposed to be. Besides, the informant had successful teaching experience in the past which in that practice the students play certain roles. Moreover, the method or approach of teaching used by the teacher directed her beliefs as well.

On the other hand, T1 claimed,

"...I had been teaching for more than 10 years. So, I know what to do....I studied how to implement MALL effectively for about last two years...I adapt with the use of MALL as the main media of learning which most likely changes the way I teach and students learn" (T1, 2020).

The claim above indicates the factors determining T1 beliefs which were derived from mature practices, philosophies based on research or education, and beliefs acquired from method or approach. The informant stated that he had very long experiences as teacher so that he knew what the best for the students including what the role of students they were supposed to be. In addition, he got his beliefs about the students' role from the research he conducted himself or other researcher. His previous education like in university also gave a portion in shaping his beliefs about the students' role. Furthermore, the method or approach he used, which was using MALL, had a role in leading his beliefs regarding students' role.

\section{DISCUSSION}

In general, the findings of this research supported the previous theories. First, this research found that the students should act as passive receptor. It was in accordance to Richards and Rodgers (2014) explanation that in this role, students are "required simply to listen and repeat what the teacher says and to respond to questions and commands." In addition, Fauziati (2014) asserts that the students have a passive role which have no control over the classroom content and activities. They just sit and listen to the teacher's explanation, do the task assigned for them, and reply the questions delivered by the teacher. They do not need to react actively or propose their idea to their teachers or their classmates. This was because normally, when the students think they know nothing and want to learn, they tended to act as an empty glass who was ready to be fulfilled with the knowledge from the teachers. Concisely, in terms of students' role as passive receptor, the findings of this research supported the earlier results.

Afterwards, this research revealed that the discovered students' roles were participant. The T2 testimony was coherent with Richards and Rodgers (2014) who described this role as the students who actively engage and participate in the process of learning as well as actively find the strategies to understand the lesson. Besides, Fauziati (2014) added that students are able to check their learning progress even set their own learning goals. Furthermore, Davis (2009) stated that student who act as participant is likely to create conducive classroom environment. The agreement between the findings of this research and the findings of prior research was because the paradigm shifts in teaching and learning practices which encourage the students to be more active in the classroom. Besides, this was because part of community language learning method. Briefly, those theories were supported by the findings if this research in terms students' role as participant. Subsequently, this research discovered that the students' role accepted as true by the teachers was initiator. It supported Richards and Rodgers (2014) description about the students as initiators that they are courageous to express their thought and even negotiate with the teacher everything related to classroom activities. Besides, Fauziati (2014) averred that students mostly confirm their understanding related to the instruction and material given by their teacher. Meanwhile, both Richards and Rodgers (2014) and Fauziati (2014) joined the characteristics that define students as initiator in which students are brave to talk and discuss with their teacher about difficulties they had in understanding material or instruction in order to find solution. Furthermore, students are also audacious to keep in touch with their teacher in order to communicate the whole thing in relation to the learning process in the classroom even outside. Furthermore, Abdullah, Bakar, and Mahbob (2012) assert that students are proactive to seek knowledge inside and outside classroom. The accordance between the results of this research and those theories was because the development of teaching and learning practices which demand the students to be more creative. It encourages them to actively initiate and create something which contributes to their success in learning. Besides, this was part of students centered learning and autonomous learning. Therefore, the findings of this research were still in accordance to the previous findings.

In addition, this research showed that the students' role expected by the teachers was performer. It was supported by Richards and Rodgers (2014) who delineate students' role as performer that they keenly react the instruction and explanation from the teacher. They feel free to criticize or give a feedback towards their colleagues' opinion and state the problems which are likely obstruct the process of teaching and learning. Meanwhile, Stroinigg (1980) as cited in Fauziati (2014), Richards and Rodgers (1992) as cited in Fauziati (2014), and Richards and Rodgers (2014) describe students' role as performer as they deliver their understanding regarding the lesson and share their thought and feeling about the class activities including their uncomprehend instruction or assignment given by the teacher. The findings of this research were coherent to the previous theories because the demand from the teachers for the students to be responsive and vocal 
in the classroom. Moreover, this was part of communicative language teaching method which emphasizes the interaction between the students and the teacher.

Furthermore, the research findings revealed the factors contributed to the teachers' beliefs. It was captured that the factors shaping T2 beliefs came from teacher's very experience as language learner, successful practice of what runs best in the past, and values acquired from a method or approach. This all was supported by Kindsvatter, Willen, and Ishler (1988) as cited in Richards and Lockhart (1994). The findings of this research corresponded to the previous theories because those factors were the prominent source which could strongly able to lead the teachers' beliefs. There is no stronger factors than those sources of beliefs which shaping the beliefs of the teachers. The similar results were also found in T1 beliefs. The finding discovered the factors determining T1 beliefs which were derived from mature practices, philosophies based on research or education, and beliefs acquired from method or approach. This was also in accordance to the research from Kindsvatter, Willen, and Ishler (1988) as cited in Richards and Lockhart (1994).

Generally, the findings of this research supported the previous research findings and theories. There were no substantial and major differences between teachers' beliefs in students' role when learning through MALL and direct physical meeting in the classroom. This was because basically the teaching and learning process was same and the difference was only in media of meeting. MALL made the teachers and the students able to have teaching and learning activity from distance without direct physical meeting. Meanwhile, conventional teaching and learning process is held in the classroom which need physical presence. Besides, the findings about the factors shaping teachers' beliefs also corresponded the previous theories because there were no significant factors which could drive teachers' beliefs other than those factors. Although this research findings were in agreement with the existing theories, it should be bear in mind that the teaching and learning process in this research was through MALL which could give new insight on how the students' should act in teaching and learning process through MALL.

\section{CONCLUSION AND SUGGESTIONS}

To sum up, this research discovered both students' roles in learning English through MALL seen from teachers' beliefs perspectives and the factors contributing their beliefs. In terms of teachers' beliefs about students' roles in learning English through MALL, it revealed that the participants accepted as true that students should play role as participant, initiator, performer, and passive receptor. Both participants agreed in the students' role as performer whereas the rest were different. Afterwards, the factors contributing to their beliefs were teachers' very experiences as language learners, successful practice of what runs best previously, mature practices, values based on research or education, and philosophies acquired from a method or approach. The only agreed factor from both participants was the last one. Overall, the results were in compliance with

Despite the results acquired and analyzed in this research, it still needs some suggestions. First, other elements of English teaching and learning are fascinating to be explored, in light of teachers' beliefs study, such as teachers' roles, the roles of instructional materials, types of learning and teaching activities, etc. Subsequently, specific skill in English learning like reading, listening, speaking, writing, grammar, etc. should be investigated as well.

\section{REFERENCES}

Abdullah, M. Y., Bakar, N. R., \& Mahbob, M. H. (2012). Student's participation in classroom: What motivates them to speak up? Procedia Social Behavioral Sciences, 51, 516-522. doi:10.1016/j.sbspro.2012.08.199.

Ataman,E. (2020). The investigation of english teachers' views on computer assisted language learning. The Universal Academic Research Journal, 2(1)46-57.

Borg, S. (2003). Teacher cognition in language teaching: A review of research on what language teachers think, know, believe, and do. Language Teaching, 36(2), 81-109. doi:10.1017/S0261444803001903

Burston, J. (2013). Mobile-assisted language learning: A selected annotated bibliography of implementation studies $1994-$ 2012. Language Learning and Technology, 17(3), 157-256.

Clark, C., \& Peterson, P. (1986). Teachers' Thought Processes. In M. Wittrock, Handbook of Research on Teaching (3rd ed., pp. 255-296). New York: Macmillan.

Davis, B. G. (2009). Tools for Teaching (2nd ed.). San Fransisco: Jossey-Bass.

Duman,T. \& Karagöz,S. (2016). An evaluation of Turkish teacher education system compared to other models in different countries. International Journal of Educational Research Review,1(1),1-13.

Ertmer, P. A., Ottenbreit-Leftwich, A. T., Sadik, O., Sendurur, E., \& Sendurur, P. (2012). Teacher beliefs and technology integration practices: A critical relationship. Computers and Education, 59(2), 423-435. doi:10.1016/j.compedu.2012.02.001

Fauziati, E. (2014). Methods of Teaching English as a Foreign Language (TEFL): Traditional method, designer method, communicative approach, scientific approach. Surakarta, Era Pustaka Utama.

Fauziati, E. (2017). Teaching english as a foreign language: Principle and practice. Surakarta: Era Pustaka Utama.

Geddes, S. J. (2004). Mobile learning in the 21st century: Benefit to learners. Knowledge Tree e-Journal, 30(3), 214-228.

Gilakjani, A. P., \& Sabouri, N. B. (2017). Teachers' beliefs in English language teaching and learning: A review of the literature. English Language Teaching, 10(4), 78-86. doi:10.5539/elt.v10n4p78

Huang, L.-L., \& Lin, C.-C. (2011). EFL learners' reading on mobile phones. The JALT CALL Journal, 7(1), 61-78. 
Jee, M. J. (2011). Web 2.0 technology meets mobile assisted language learning. IALLT Journal of Language Learning Technologies, 41(1), 161-175.

Khubyari, L., \& Narafshan, M. H. (2016). A study on the impact of of mall (mobile assisted language learning) on efl learners' reading comprehension. International Journal of English Language Teaching, 4(2), 58-69.

Klopfer, E., Squire, K., \& Jenkins, H. (2002). Environmental detectives: PDAs as a window into a virtual simulated world. International Workshop on Wireless and Mobile Technologies in Education (pp. 95-98). Tokushima: IEEE. doi:10.1109/WMTE.2002.1039227

Kuzborska, I. (2011). Links between teachers' beliefs and practices and research on reading. Reading in a Foreign Language, 23(1), 102-108. Retrieved from http://nflrc.hawaii.edu/rfl

Lan, Y. F., \& Sie, Y. S. (2010). Using RSS to support mobile learning based on media richness theory. Computers and Education, 55(2), 723-732.

Larenas, C. D., Hernandez, P. A., \& Navarrete, M. O. (2015). A case study on EFL teachers' beliefs about the teaching and learning of English in public education. Porta Linguarum, 23, 171-186.

Larsen-Freeman, D., \& Anderson, M. (2013). Technique and principles in language teaching (3rd ed.). New York: Oxford.

Lee, H. (2013). Conjoint analysis for mobile devices for ubiquitous learning in higher education: The Korean case. Turkish Online Journal of Educational Technology, 12(1), 45-51.

Miangah, T. M., \& Nezarat, A. (2012). Mobile-Assisted Language Learning. International Journal of Distributed and Parallel Systems, 3(1), 309-3019. doi:10.5121/ijdps.2012.3126

Miles, M. B., Huberman, A. M., \& Saldana, J. (2104). Qualitative data analysis: A methods sourcebook (3rd ed.). Thousand Oaks, CA: SAGE.

Motallebzadeh, K., \& Ganjali, R. (2011). SMS: Tool for L2 vocabulary retention and reading comprehension ability. Journal of Language Teaching and Research, 2(5), 1111-1115. doi:10.4304/jltr.2.5.1111-1115

Pajares, M. F. (1992). Teachers' beliefs and educational research: Cleaning up a messy construct. Review of Educational Research, 62(3), 307-332. doi:10.3102/00346543062003307

Picton, I. (2019). Teachers' use of technology to support literacy in 2018. London, UK: National Literacy Trust. Retrieved June 26, 2020, from https://cdn.literacytrust.org.uk/media/documents/Teachers_Use_of_Technology_report.pdf

Richards, J. C., \& Lockhart, C. (1996). Reflective teaching in second language classrooms. New York: Cambridge University Press. Retrieved from www.cambridge.org/9780521458030

Richards, J. C., \& Rodgers, T. S. (2014). Approaches and methods in language teaching (3rd ed.). Cambridge: Cambridge University Press.

Stuart, C., \& Thurlow, D. (2000). Making it their own: Pre-service teachers' experiences, beliefs, and classroom practices. Journal of Teacher Education, 51(2), 113-121. doi:10.1177/002248710005100205

Valarmathi, K. E. (2011). Mobile assissted language learning. Journal of Technology for ELT, 2(2), 16-23.

Williams, C. (2020, June 26). Enter the Classroom of the Future. Retrieved from Apps Apple: https://apps.apple.com/gb/story/id1427202128

Yin, R. K. (2018). Case Study Research and Applications: Design and Methods (6th ed.). London, UK: SAGE Publications Inc.

Yudhiantara, R., \& Nasir, I. A. (2017). Toward mobile-assisted language learning (MALL): Reaping mobile phone benefits in classroom activities. Register Journal, 10(1), 12-28. doi:10.18326/rgt.v10i1.12-28 